\title{
Variability in quality attributes of sugar cane (Saccharium officinale) clones as influenced by Nitrofertigation in Southern Nigeria
}

\begin{abstract}
An experiment was carried out in 2017 and 2018 planting seasons in Calabar, Southern Nigeria to evaluate the influence of nitrogen fertilizer on quality attributes of three clones of Sugarcane. The trial was laid out in $3 \times 4$ Split-plot in a randomized complete block design with 3 replications. The main plot was the three cane varieties $(\mathrm{KN}-10$; OG-11 and OY-10), while the sup-plots consisted of the nitrogen fertilizer rates-0, 60, 90 and 120kgha-1N, (Symbolized $\mathrm{N}_{1}, \mathrm{~N}_{2}, \mathrm{~N}_{3}$ and $\mathrm{N}_{4}$ respectively). The results showed that none of the clones matured before the 12th month of growth, hence juice analysis took place from the $291^{\text {st }}$ day, for better brix, pol, purity and C.C.S quality attributes. Varietal differences as influence by treatment was glaring. The variety $\mathrm{KN}-10$ at the application of $60 \mathrm{kgha}^{-1} \mathrm{~N}$ had brix $19.5 \%$; pol $18.4 \%$; purity $85.5 \%$; cane yield 73.53 (tons/ha); average yield of sugar 9.0 (tons/ha), compared with $0 \mathrm{kgha}$ ${ }^{1} \mathrm{~N}$, and these values were significantly $(\mathrm{P}<0.05)$ higher than values obtained from either OG -11 or $\mathrm{OY}-10$, given similar experimental conditions. The highest fibre content $18.4 \%$ was obtained from OY-10, where $120 \mathrm{kgha}^{-1} \mathrm{~N}$ was applied. Most of the variations due to nitrogen was accounted for by a quadratic type, response curve. These results are discussed in relation to future fertilizer experiments envisaged for the potential sugarcane land in Southern Nigeria.
\end{abstract}

Keywords: NPK, fertilizer application, clonal attributes, sugar cane germplasm, brix and pol content

\section{Introduction}

Hardly are there any agronomic research conducted on sugarcane in Calabar, the South- South of Nigeria. Much of the researches done on sugarcane are done in the North and South West of Nigeria, inspite of the fact that much Sugar Cane is grown by farmers in the South by fragmentation. However, most of the industries using Sugar Cane as raw materials are found in Northern Nigeria and that has consequently limited production in the South, which is far away from the industries.

There are four Sugar Cane estates prominent in Nigeria:- Bacita, Numan, Sunti and Lafiagi. These estates grow sugarcane in relatively large scale while the majority of the small holder farmers grow soft sugar cane (Chewing Cane) on land holding 0.2-0.5 hectare. ${ }^{1}$ Sugar Cane is grown in 25-30,000ha in Nigeria of which industrial cane covers 12,000ha. ${ }^{2}$ Agboire et al., ${ }^{3}$ reported that fertilizer for cane production could be applied at $200 \mathrm{~kg} \mathrm{~N}, 100 \mathrm{~kg} \mathrm{P}_{2} \mathrm{O}_{5}$ and $180 \mathrm{~kg} \mathrm{~K}_{2} \mathrm{O} /$ ha on Sandy loam soil containing $4.6 \%$ organic carbon; $0.07 \%$ organic matter; $0.62 \%$ total nitrogen; $0.050 \mathrm{meg} / 100 \mathrm{~g}$ exchangeable $\mathrm{K}$ and $87.8 \%$ Sand; $11.0 \%$ Silt and 1.2\% Clay. Sugar Cane is in high demand all over Nigeria for both individual and industrial uses and canes are sold in all big cities and State capitals across the Nation because of its nutritional value. There had been dearth of information on this crop in the south. It was on this consideration that this study was conducted in Calabar, Southern Nigeria, to evaluate the yield qualities of three clones of sugar canes, commonly grown in Nigeria, as influenced by nitrogen application.

\section{Materials and methods}

The trial was carried out in 2017 and 2018 planting seasons, in Calabar, Southern Nigeria, which lies between latitude $05^{0} 32^{1}$ and
Volume 3 Issue 6 - 2018

\author{
Ubi William,' Ubi Godwin Michael $\left.\right|^{2}$ \\ 'National Open University of Nigeria, School of Science and \\ Technology, Nigeria \\ ${ }^{2}$ Department of Genetics and Biotechnology, University of \\ Calabar, Nigeria
}

Correspondence: Ubi Godwin Michael, Department of Genetics and Biotechnology, University of Calabar, Nigeria, Email ubiology.gw@gmail.com, ubi850@yahoo.com

Received: September 05, 2018 | Published: November 28 2018

$04^{0} 27^{1} \mathrm{~N}$ and longitude $07^{0} 15^{1}$ and $09^{0} 28^{1} \mathrm{E}$. The area is of humid tropical climate, characterized by high rainfall with two main seasons, dry and rainy seasons. The vegetation is tropical rain forest of humid agro-ecological zone in Nigeria. According to USDA System of classification. ${ }^{4}$ Calabar Soils are typic paleuduct. The soil is acid sands derived from coastal plain sands, consisting of sand deposits which lie across Cross River and under lain by massive deposits of limestone, quartz, $\mathrm{Fe}$ and $\mathrm{Al}$ oxides which dominate the soil with kaolinite as clay mineral and the soil texture is sandy loam.

\section{Land preparation}

The experimental field was cited on flat land at Calabar. The land was manually cleared with matchet, gathered together and removed. The area was leveled and marked out with wooden Pegs for planting. The initial soil characterization was already done in our previous studies.

\section{Planting materials}

The three varieties of sugar cane Germplasms used included: $\mathrm{KN}-10$, with green stalk colour; OG -11, with brown stalk colour and OY-10, with purple stalk colour. These varieties were selected and obtained from Kano, Ogun and Oyo states to study their adaptability in Calabar, South South Nigeria.

\section{Fertilizer}

Since the average $\mathrm{P}^{\mathrm{H}}$ of the soil was 4.4 , no liming was essential as Sulphate of ammonia was being used extensively in this part of the country, and was chosen as the source of nitrogen for the study. Phosphate $\left(\mathrm{P}_{2} \mathrm{O}_{5}\right)$ was applied as double super phosphate, potassium as muriate of potash $\left(\mathrm{P}_{2} \mathrm{O}\right)$ and magnesium as magnesium sulphate 
$\left(\mathrm{MgSO}_{4}\right)$. A basal application of $100 \mathrm{~kg} \mathrm{P}_{2} \mathrm{O}_{5}$ and $180 \mathrm{~kg} \mathrm{~K} \mathrm{~K}_{2} \mathrm{O}$ and 50 $\mathrm{MgSO}_{4}$ was applied to all sub-plots as blanket application before planting.

\section{Experimental design}

The trial was carried out to determine the response of three sugar cane progenies to different levels of nitrogen $(\mathrm{N})$, fixing phosphate $\left(\mathrm{P}_{2} \mathrm{O}_{5}\right)$ and potash $\left(\mathrm{K}_{2} 0\right)$ at $100 \mathrm{~kg} \mathrm{P}_{2}{ }^{0} 5$ and $180 \mathrm{~kg} \mathrm{~K}_{2} 0 /$ ha respectively. The design was split-plot design with 4 levels of nitrogen $(0,60,90$, $120 \mathrm{kgha}^{-1}$ ), replicated 3 times, with 48 sub-plots. The Germplasm (clones) formed the main treatment while the sub-plot was the fertilizer levels. An area of $2^{2} \mathrm{~m}$ was marked out per plot as sampling area.

\section{Planting}

The cutting materials or setts of $30 \mathrm{~cm}$ long were selected, dipped in mercurial and insecticidal solutions drained off and then planted. Planting was $30 \times 30 \mathrm{~cm}$ within rows and $50 \mathrm{~cm}$ between rows, giving a plant population of 16,135 plants per hectare.

\section{Statistical analysis}

Field data were subjected to analysis of variance (ANOVA) and means compared using Fishers Least Significant Difference at 5\% probability level. ${ }^{7}$ The result of some physico-chemical properties of the soil used for the experiment is presented in Table 1, in which the small $\mathrm{P}^{\mathrm{H}}$ ranged between 4.2 to 4.6 with a mean of 4.4. On the average, the soil has organic matter $33.3 \mathrm{~g} / \mathrm{kg}$; TN1.8g/kg; Bray $1 \mathrm{P}$ $9.9 \mathrm{mg} / \mathrm{kg} ; \mathrm{Ca} 2.13(\mathrm{cmol}+) \mathrm{mg} 0.5(\mathrm{cmol}+) ; \mathrm{K} 0.4(\mathrm{cmol}+)$ and $\mathrm{Na}$ $0.3(\mathrm{cmol}+)$. Sand was $82 \%$; Silt $7 \%$; Clay $10.0 \%$; BS $25 \%$ with textural class, SL. All the soil properties tested were within their critical levels recommended for soils in this study area. ${ }^{5,7}$

\section{Cane sampling}

The canes were first sampled at the age of 291 days and thereafter, at intervals of approximately three weeks. The sampling procedure is given in Table 1. Samples were taken at random and at each sampling, only one cane was taken from each clump.

Table 1 Sampling of sugar canes for analysis

\begin{tabular}{|c|c|c|}
\hline Variety & 1st Sampling & Subsequent Sampling \\
\hline $\mathrm{KN}-10$ & $\begin{array}{l}6 \text { canes were taken from } \\
\text { were for sugar analysis }\end{array}$ & $\begin{array}{l}\text { As for } \mathrm{KN}-10 \text { above. } \\
\text { sample row for sugar analysis }\end{array}$ \\
\hline $\mathrm{OG}-11$ & As for $\mathrm{KN}-10$ above & $\begin{array}{l}9 \text { canes were taken from } \\
\text { Sample row of which } 5 \text { were } \\
\text { for sugar and } 4 \text { for fibre } \\
\text { determination. }\end{array}$ \\
\hline $\mathrm{OY}-10$ & As for $\mathrm{KN}-10$ above. & As for $O G-11$ above. \\
\hline
\end{tabular}

\section{Chemical analysis}

Analysis of juice was carried out 291 days after planting to enable the behaviour of brix, pol and purity of the cane to be traced. About $100 \mathrm{ml}$ of the juice was filtered with a $0.5 \mathrm{~mm}$ mesh screen and read-off in a Sacharimeter to give the pol content of juice. About $5 \mathrm{~g}$ each from sampling area was washed for fibre content determination (Table 1). ${ }^{1,7}$

Each sub-plot consisted of seven rows of canes. The two outermost rows and the terminal clumps of the other five rows acted as guard rows. Treatment of Samples and sub-sampling

\section{Cane analysis}

Analysis was conducted to determine the time of maturity, sugar and fibre contents of three clones. A series of analysis were carried out beginning when the canes were 219 days old, at approximately three weeks interval and terminating when they matured at 402 days.

\section{Juice}

Brix, Pol and Purity $=\left[\frac{\text { Pol }}{\text { Brix }} \times \frac{100}{1}\right]$

Each sample was first cleaned of trash and topped off. Then the canes were cut into approximately two equal halves-top and bottom halves. The juice was extracted separately for each half with a motorized Cane-crusher and the brix and pol were determined respectively.

Brix: This consists of total dissolved substance in the Juice.

Pol: Cane juice contains other optically active substance besides sucrose. The pol of a solution is the concentration of a solution of pure sucrose in water having the same optical rotation at the same temperature. The brix is the dissolved substance as determined by a hydrometer. After the brix was read off, $100 \mathrm{ml}$ of the juice was clarified with basic lead acetate, filtered and then read off in a Saccharimeter to give the POL.

(i) Fibre: Four canes were taken from each sub-plot and bulked according to treatment. Thus there were twelve canes for fibre analysis per treatment.

(ii) Yield: The terminal clump from the rest of the four rows in each sub-plot were discarded. The harvested area was therefore reduced to $0.0588-75$ ha. The canes were cut below ground level, cleaned of trash, topped and weighed.

\section{Results}

\section{Juice Analysis of Canes under different treatments (Table 2A-2C)}

The average brix, pol and purity of the juice at different ages for the three clones are shown in Table $3 \mathrm{~A}-\mathrm{C}$ respectively. The highest brix content $(19.5 \%)$ at 355 days was recorded by $\mathrm{KN}-10$ where $60 \mathrm{kgha}^{-1} \mathrm{~N}\left(\mathrm{~N}_{2}\right)$ was applied and this value was significantly $(\mathrm{P}<0.05)$ higher than all other values given similar experimental conditions, (Table 2A). The lowest value $(7.5 \%)$ at 291 days was recorded by OY-10 where $120 \mathrm{kgha}^{-1} \mathrm{~N}\left(\mathrm{~N}_{4}\right)$ was applied. Equally, the highest pol content at 402 days $(19.8 \%$ ) was recorded by OG-11, where $120 \mathrm{kgha}$ ${ }_{1} \mathrm{~N}\left(\mathrm{~N}_{4}\right)$ was applied (Table 2B). Similarly, the highest percent purity $(85.5 \%)$ was obtained from $\mathrm{KN}-10$, at 402 days where $60 \mathrm{kggha}^{-1} \mathrm{~N}$ $\left(\mathrm{N}_{2}\right)$ was applied and this values was significantly $(\mathrm{P}<0.05)$, higher than all other values obtained from either OG-11 or OY-10 at any of the days or any other fertilizer level, throughout the study season (Table $2 \mathrm{C}$ ). The highest nitrogen rate $120 \mathrm{kgha}^{-1} \mathrm{~N}$ and at any of the ages did not tend to significantly $(\mathrm{P}<0.05)$ influence the Brix, Pol and Purity of the three clones given similar experimental conditions.

The fibre contents of the three clones as influenced by nitrogen fertilizer application is presented in Table 3 . The highest fibre content (18.4), was recorded by $\mathrm{OY}-10$, where $120 \mathrm{kgha}^{-1} \mathrm{~N}$ was applied while the lowest values, $(8.4 \%)$, was obtained from $\mathrm{KN}-10$, where no fertilizer nitrogen was applied. Comparing the mean values of the 
application of $120 \mathrm{kgha}^{-1} \mathrm{~N}\left(\mathrm{~N}_{4}\right)$ with that of $60 \mathrm{kgha}^{-1} \mathrm{~N}\left(\mathrm{~N}_{2}\right)$, there was $31.7 \%$ unit increase in fibre content when nitrogen fertilizer was increased from $60 \mathrm{kgha}^{-1} \mathrm{~N}$ to $120 \mathrm{kgha}^{-1} \mathrm{~N}$.

Analysis of variance in the cane yield shows that there were significant differences at $1 \%$ level of probability (Table $4 \& 5$ ).

The results of the average yields of the three clones of sugar cane are presented in Table 5, in which the highest yield 73.53 ton/ha was obtained from $\mathrm{KN}-10$, where $60 \mathrm{kgha}^{-1} \mathrm{~N}$ was applied while the lowest 17.50 ton/ha was obtained from OY-10, where $0 \mathrm{kgha}^{-1}$ was applied. The application of $60 \mathrm{kgha}^{-1} \mathrm{~N}$ tended to give higher yield of can in $\mathrm{KN}-10$, and $\mathrm{OG}-11$, than in $\mathrm{OY}-10$. This is cost effective in that the farmer will not be spending much money to buy fertilizer for optimum yield.

Table 2A Results of Brix analysis of the three clones

\begin{tabular}{lcccccccccccc}
\hline N-levels & \multicolumn{3}{c}{ NI } & \multicolumn{3}{c}{ N2 } & \multicolumn{3}{c}{ N3 } & & N4 \\
\hline Age (days) & 291 & 355 & 402 & 291 & 355 & 402 & 291 & 355 & 402 & 291 & 355 & 402 \\
\hline Varieties & & Brix & & & Brix & & & Brix & & & Brix & \\
\hline KN - 10 & 14 & 18.5 & 16.6 & 15 & 19.5 & 17 & 14 & 15.2 & 16.3 & 12.1 & 10.6 & 13 \\
OG - 11 & 11.5 & 13.2 & 15.1 & 10.7 & 12.6 & 14.4 & 12.5 & 13.2 & 14.1 & 7.5 & 8.3 & 10.1 \\
OY - 10 & 10.2 & 12 & 14 & 9.3 & 10.5 & 13.1 & 10.3 & 11.4 & 12.6 & 7.5 & 8.3 & 10.1 \\
LSD (P<0.05) & 1.2 & 1.2 & 1.3 & 1.2 & 1.5 & 1.3 & 1.2 & 1.3 & 1.6 & 1.4 & 1.2 & 1.3 \\
\hline
\end{tabular}

Table 2B Percentage pol content of three clones

\begin{tabular}{|c|c|c|c|c|c|c|c|c|c|c|c|c|}
\hline \multirow{2}{*}{$\begin{array}{l}\text { N-levels } \\
\text { Age (days) }\end{array}$} & \multicolumn{3}{|c|}{ NI } & \multicolumn{3}{|c|}{$\mathbf{N} 2$} & \multicolumn{3}{|c|}{$\mathbf{N 3}$} & \multicolumn{3}{|c|}{ N4 } \\
\hline & 291 & 355 & 402 & 291 & 355 & 402 & 291 & 355 & 402 & 291 & 355 & 402 \\
\hline Varieties & & Brix & & & Brix & & & Brix & & & Brix & \\
\hline $\mathrm{KN}-10$ & 10.5 & 13.3 & 15.1 & 13.2 & 15.6 & 18.4 & 10.6 & 12.1 & 15.6 & 10.4 & 11.8 & 14.6 \\
\hline OG - 11 & 9.5 & 10.6 & 12.5 & 12.0 & 16.7 & 19.8 & 9.5 & 10.0 & 14.4 & 8.6 & 10.6 & 13.4 \\
\hline OY - 10 & 8.4 & 9.0 & 10.2 & 10.4 & 14.1 & 16.2 & 8.3 & 9.3 & 12.0 & 7.1 & 8.8 & 12.2 \\
\hline LSD $(\mathrm{P}<0.05)$ & 0.75 & 1.6 & 2.1 & 1.2 & 1.1 & 1.4 & 1.1 & 1.1 & 1.2 & 1.3 & 1.2 & 1.2 \\
\hline
\end{tabular}

Table 2C Percentage purity of three clones

\begin{tabular}{|c|c|c|c|c|c|c|c|c|c|c|c|c|}
\hline \multirow{2}{*}{$\begin{array}{l}\text { N-levels } \\
\text { Age (days) }\end{array}$} & \multicolumn{3}{|c|}{ NI } & \multicolumn{3}{|c|}{$\mathbf{N} 2$} & \multicolumn{3}{|c|}{$\mathbf{N 3}$} & \multicolumn{3}{|c|}{ N4 } \\
\hline & 291 & 355 & 402 & 291 & 355 & 402 & 291 & 355 & 402 & 291 & 355 & 402 \\
\hline Varieties & & Brix & & & Brix & & & Brix & & & Brix & \\
\hline $\mathrm{KN}-10$ & 74.5 & 80.3 & 82.5 & 75.4 & 82.6 & 85.5 & 71.6 & 78.6 & 81.2 & 60.8 & 72.1 & 78.2 \\
\hline OG - 11 & 62.4 & 73.5 & 74.6 & 71.2 & 73.4 & 80.1 & 68.2 & 71.3 & 73.4 & 58.2 & 62.4 & 68.0 \\
\hline OY - 10 & 58.1 & 61.4 & 71.2 & 66.7 & 71.1 & 76.0 & 61.0 & 64.1 & 66.0 & 59.6 & 60.1 & 63.9 \\
\hline LSD $(P<0.05)$ & 1.2 & 1.2 & 1.6 & 2.4 & 1.8 & 3.2 & 3.1 & 3.2 & 6.1 & 1.2 & 1.3 & 4.5 \\
\hline
\end{tabular}

Table 3 Mean Values of Fibre Contents (\%) of the three Clones at 4 Nitrogen Levels

\begin{tabular}{lllllll}
\hline N-levels & NI & N2 & N3 & N4 & Mean & LSD \\
\hline Varieties & & & & & & \\
\hline KN - 10 & 8.4 & 10.3 & 12.2 & 14.1 & 11.25 & 1.5 \\
OG - 11 & 9.0 & 12.1 & 14.2 & 16.0 & 12.83 & 1.8 \\
OY - 10 & 16.8 & 14.4 & 16.5 & 18.4 & 15.00 & 2.1 \\
Mean & 9.4 & 12.3 & 14.3 & 16.2 & & \\
LSD $(\mathrm{P}<0.05)$ & 0.5 & 1.5 & 2.0 & 1.8 & & \\
\hline
\end{tabular}


Table 4 Yield of sugar cane (ANOVA) analysis of variance

\begin{tabular}{lll}
\hline Source of variation DF & MS & F \\
\hline Main plot & & \\
\hline Reps $3-1=2$ & 3493.33 & $0.1498 \mathrm{NS}$ \\
Clone $3-1=2$ & 2677095.50 & 114.82 \\
Error (a) 4 & 23314.14 & - \\
Total 8 & - & \\
\hline Sub-plot & & \\
\hline N $4-1=3$ & 25763.94 & 0.8402 \\
Clone x N = 2 x 3 =6 & 37767.66 & 1.231 \\
Error (b) 6 x $3=18$ & 30664.018 & - \\
Grand Total 35 & - & - \\
\hline
\end{tabular}

Table 5 Average yield (tons/ha) of clones in relation to nitrogen treatment

\begin{tabular}{llll}
\hline \multirow{2}{*}{ Treatment } & \multicolumn{2}{l}{ Varieties } & \\
\cline { 2 - 4 } & KN - 10 & OG - 11 & OY - 10 \\
\hline N1 O kg/ha & 68.80 & 61.30 & 17.50 \\
N2 $60 \mathrm{~kg} / \mathrm{ha}$ & 73.53 & 70.13 & 24.73 \\
N3 $90 \mathrm{~kg} / \mathrm{ha}$ & 69.13 & 60.10 & 38.00 \\
N4 $120 \mathrm{~kg} / \mathrm{ha}$ & 71.25 & 70.28 & 30.30 \\
LDS $(\mathrm{P}<0.05)$ & & & \\
SEM =0.964 & 2.1 & 1.2 & 5.1 \\
CV $=15.00 \%$ & & & \\
\hline
\end{tabular}

\section{Commercial cane sugar}

The analysis of variance (ANOVA) of the main plot (Table 6) has shown that varietal difference among the three clones was significant $(\mathrm{P}<0.01)$. The sub-plot effect involving the effect of nitrogen on the three clones was significant $(\mathrm{P}<0.05)$. The interactions of variety $\mathrm{x}$ nitrogen was significant $(\mathrm{P}<0.01)$.

Table 6 Analysis of variance

\begin{tabular}{llll}
\hline Source of variation & DF & MS & F \\
\hline Main plot & 2 & 0.1762 & $0.2157 \mathrm{NS}$ \\
\hline Reps $3-1=$ & 2 & 34.89884 & 2.7262 \\
Clone $3-1=$ & 4 & 0.8168 & \\
Error & 8 & & \\
Total $=$ & & & \\
\hline Sub-plot & 3 & 2.6035 & 3.9039 \\
\hline $\mathrm{N}=4-1=$ & 6 & 2.8473 & 1.2705 \\
Clone $\mathrm{N}$ N $=3 \times 2=$ & 18 & 0.6669 & \\
Error $(\mathrm{b})=3 \times 6=$ & 35 & & $\mathrm{P}<0.05$ \\
Grand Total $=$ & & & \\
& & & \\
\end{tabular}

The analysis of variance (ANOVA) in Table 6 showed that the main effect of nitrogen fertilizer on the performance of the clones was significant $(\mathrm{P}<0.001)$, in which varietal differences in all parameters studied was glaring. The effect of nitrogen as it relate to varietal performance was significant $(\mathrm{P}<0.10)$. in the sub-plot, the interaction between nitrogen $x$ variety was significant $(P<0.05)$, in which the varieties had their maximum performance at different nitrogen levels.

Table 7 shows the interaction between nitrogen levels and varieties performance on yield (ton/ha), in which the application of $60 \mathrm{kgha}^{-1} \mathrm{~N}$ where $\mathrm{KN}-10$ was planted gave $9.0\left(\right.$ ton $\left./ \mathrm{ha}^{-1}\right)$ of sugar, which was significantly $(\mathrm{P}<0.05)$ higher than values obtained from all other varieties and $\mathrm{N}$-rates given similar experimental conditions. The lowest sugar value 2.0 (ton/ha) was obtained from OY-10, where $60 \mathrm{kgha}^{-1} \mathrm{~N}$ was applied. This shows that different varieties of a crop reaction differently to the same fertilizer level.

Table 7 Average Yield (tons/ha) of Sugar as influenced by Nitrogen fertilizer application

\begin{tabular}{llll}
\hline \multirow{2}{*}{ Treatment } & \multicolumn{2}{l}{ Varieties } & \\
\cline { 2 - 4 } & KN - 10 & OG - 11 & OY - 10 \\
\hline N1 O kg/ha & 7.4 & 6.5 & 2.1 \\
N2 $60 \mathrm{~kg} / \mathrm{ha}$ & 9.0 & 7.8 & 2.0 \\
N3 $90 \mathrm{~kg} / \mathrm{ha}$ & 7.5 & 6.5 & 3.2 \\
N4 $120 \mathrm{~kg} / \mathrm{ha}$ & 7.8 & 7.1 & 7.4 \\
Mean & 7.8 & 6.9 & 3.6 \\
LDS $(\mathrm{P}<0.05)$ & 0.3 & 0.3 & 1.2 \\
\hline
\end{tabular}

From Table 8, the clonal effect on Commercial Cane Sugar C.C.S was highly significant while that of $\mathrm{N}$ was significant at $5 \%$ probability level only. Again, it was found that clones $\mathrm{KN}-10$ and OG-11, were better yielders of Sugar. Table 8, also indicates that the highest C.C.S value (12.98) was obtained from $\mathrm{KN}-10$, where $60 \mathrm{kgha}^{-1} \mathrm{~N}$ was applied while the lowest (7.13) came from OY-10, where $120 \mathrm{kgha}^{-1} \mathrm{~N}$ was applied.

Table 8 Average commercial cane sugar (C.C.S) of three clones as influenced by Nitrogen fertilizer treatment

\begin{tabular}{llll}
\hline \multirow{2}{*}{ Treatment } & \multicolumn{2}{l}{ Varieties } & \\
\cline { 2 - 4 } & KN - 10 & OG - 11 & OY - 10 \\
\hline N1 O kg/ha & 10.95 & 10.95 & 8.55 \\
N2 $60 \mathrm{~kg} / \mathrm{ha}$ & 12.98 & 11.62 & 8.05 \\
N3 $90 \mathrm{~kg} / \mathrm{ha}$ & 10.05 & 10.11 & 9.12 \\
N4 $120 \mathrm{~kg} / \mathrm{ha}$ & 9.00 & 8.25 & 7.13 \\
$\mathrm{LDS}(\mathrm{P}<0.05)$ & 1.3 & 1.2 & 0.50 \\
$\mathrm{SEM}=$ & 0.60 & & \\
C.V $=$ & $4.00 \%$ & &
\end{tabular}

Most of the variations due to $\mathrm{N}$ application could be accounted for by a quadratic type response curve. Figure 1 showed that maximum percentage sugar was close to $\mathrm{N}_{2}$. From the analysis of the data, the indicated maximum C.C.S or percentage sugar would be at approximately $60 \mathrm{kgha}^{-1} \mathrm{~N}$. Since sugar in the cane is a products of weight of canes and C.C.S, the results in Table 8 will be related to C.C.S. In this case, $\mathrm{KN}-10$ and $\mathrm{OG}-11$ are significantly $(\mathrm{P}<0.05)$ high yielding in Sugar than OY-10 at the application of $60 \mathrm{kgha}^{-1} \mathrm{~N}\left(\mathrm{~N}_{2}\right)$ under similar experimental conditions. 


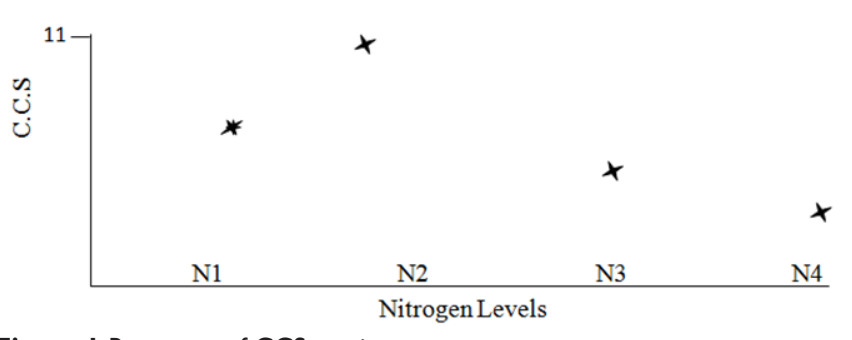

Figure I Response of CCS to nitrogen.

\section{Discussion}

The incorporation of NPK mixture into the soil in this study was essential to the establishment of healthy crop. ${ }^{2,8,9}$ The phosphate promotes a strong root system which is basic to the rapid early growth of primary shoots. Early records in this work showed that none of the clones matured before the $12^{\text {th }}$ month of growth. Therefore, analysis of the juice only took place from the $291^{\text {st }}$ day to enable the content of brix, pol, purity and C.C.S in the cane to be ascertained. ${ }^{10,11}$ As the brix only gives a rough indication of the sugar content, it is the C.C.S that determines maturity and thus the time of harvest. ${ }^{6,12}$ In this study, the brix, pol, purity and C.C.S values were higher in the lowest level of nitrogen application $60 \mathrm{kgha}^{-1} \mathrm{~N}$ indicating that the cane quality is not related to high levels of nitrogen in this study area. Similar results were earlier reported. ${ }^{3,13}$ The implication is that, Sugar content of mature Cane is retarded by high rate of $\mathrm{N}$. there was therefore inverse relationship between increased $\mathrm{N}-$ levels and Sugar content of the three clones.

In the three clones, the fibre content increased with a corresponding increase in $\mathrm{N}$-fertilization even in the early stages of the experiment, ${ }^{6,13}$ this positive effect of applied $\mathrm{N}$ on the fibre content is attributed to the lignifications process occurring later in the season, requiring lower rates of $\mathrm{N}$; rather than higher rates of $\mathrm{N}^{10,14,15}$ Thus, the positive effect of applied $\mathrm{N}$ on the fibre content coupled with its effect in reducing the brix, pol, purity and C.C.S values at higher rates later in the season led to the high fibre contents of the canes from plots with high $\mathrm{N}-$ rates. ${ }^{16-18}$ It was noted at all stages of growth that $\mathrm{N}-$ fertilizer was adequately required to keep the canes at their optimizing performance. ${ }^{19}$ As the canes mature, the change from $\mathrm{N}$ increasing to rather $\mathrm{N}$ retarding quality occurred at the same time, such that the effect of $\mathrm{N}$ fertilizer accounts for only $8 \%$ to cane quality, later in the season. It was also observed that the rate of post-sugar formation seems likely to be related to the period of the formation of pre-cane quality, earlier in the season. More investigation may be required before the relationship could be meaningfully understood. ${ }^{20}$

\section{Conclusion}

An experiment carried out to evaluate four levels of nitrogen with three clones of sugar cane was laid out in sandy loam soil. During the experiment, measurements of brix, pol, purity, C.C.S and fibre contents were determined. Varietal differences were noted in all parameters measured. The evidence derived from this study showed that high level of $\mathrm{N}$ above $60 \mathrm{kgha}^{-1}$ was detrimental to quality of cane. Fertilization of either of the three clones with $\mathrm{N}$-fertilizer at $60 \mathrm{kgha}$ ${ }^{1} \mathrm{~N}$, would be cost effective with good quality canes and greater economic returns to the farmer. Most of the variations due to nitrogen were accounted for by a quadratic type response curve. Maximum sugar would be produced using $60 \mathrm{kgha}^{-1} \mathrm{~N}$.

\section{Acknowledgment}

The authors which to acknowledge the Training and Technical Assistance Department of the Cross River State Fadama Development project and the research coordinating unit of Farm focus international. org.ng.

\section{Competing interest}

The authors declare that there are no competing interests in this manuscript.

\section{Author's contribution}

All authors contributed immensely to the development of this manuscript from the design, writing of manuscript sections, statistical analysis, proof reading/editing and financial contribution.

\section{References}

1. AOAC. Association of official Analytical Chemists official method of Analysis. $15^{\text {th }}$ edn. USA: Association of Official Analytical Chemists; 1990.

2. Akobundu IO. Weed science in the Tropics, Principles and practice. New York: CAB Direct; 1987.

3. Agboire S, AC Wada, MN Ishaq. Evaluation and characterization of Sugar Cane Germplasm Accessions for their breeding values in Nigeria. Journal of Food Technology in Africa. 2002;7(1):33-35.

4. Soil survey staff. Report of soil analyses in south Nigeria. 1998.

5. FAO. Food and Agricultural Organization. Italy. 1998.

6. Ubi W, CPE Omaliko, MW Ubi, et al. Effect of N-Fertilizer application on the brix, pol, fibre and purity of two Pineapple Cultivars (Ananas Comosus). Global Journal of Agricultural Sciences. 2006;5(1):57-59.

7. Faithful NT. Determination of small silage sample. Journal of the University of Wales Agricultural Society. 1997;101-114.

8. Christie GA. The value of early Fertilizing. The Cane Gromer's Quarterly Bull. 1964;28(2):67.

9. Aikulola EO. Problems of Sugar Cane farmers in Nigeria in pro-inst. Nigeria: NCRI; 1978. p. 17-19.

10. Anonymous. Sugar Cane varietal Development and Research in Nigeria. Nigeria: NCRI; 1997.

11. Fry J. A global perspective of the Sugar Industry in intensive Sugar Cane production. UK: CAB; 1997. p. 1-16.

12. Hutchinson PB, F Daniel. A rating scale for Sugar Cane characteristics in proc. Xiv ${ }^{\text {th }}$ ISSCT Congress. USA: Baton Rouge Lansiana;1971. p. 128-131.

13. Naidu KM. Potential yield in Sugar Cane and its realization through variety improvement. Sugar Cane. 1987. p. 1-17.

14. Varietal improvement. In: MK Naidu, JV Screenivassan, MN Prenachandran, editoirs. India: Sugar Cane Breeding Institute Coimbatore;

15. Morton JF. Fruits of warm climates. Creative Resources System. 1987; p. $18-28$.

16. Sampson JA. Tropical Fruits. $2^{\text {nd }}$ edn. Longman Scientific and Technical. 1986; p. 190-215.

17. Ubi W, CPE Omaliko. Influence of harvesting management and 
nitrogen fertilizer application on plant fractions in field Swards. Global Journal of Pure and Applied Sciences. 2004;10:535-543.

18. Ubi W, Igwe H, Ekpe S. et al. Preliminary trial of fertilizer types on pineapple (Ananas Comosus) grown on coastal acid sands of Cross River State, Nigeria. Global Journal of Pure and Applied Science. 2005;11(4):457-460.
19. Wahau TAT. Changes in Enzymes Activities of Clarias Gariepinus Brood Fish Exposed to Anaesthetics Metomidate. Applied Statistics for Scientific Studies African. 1999;1(3):37-40.

20. Wada AC. Some important disease and pests of Sugar Cane in Nigeria and their control. Outlook on Agriculture. 1997;3(2):101-105. 